\title{
Intravenous immunoglobulin for prophylaxis of neonatal sepsis in premature infants
}

\author{
A STABILE, S MICELI SOPO, V ROMANELLI, M PASTORE, AND M A PESARESI \\ Department of Paediatrics, Catholic University, Rome, Italy
}

SUMmaRY The incidence of sepsis, mortality due to sepsis, total mortality, and minor infections was evaluated in a group of 46 premature newborn infants who were treated with intravenous immunoglobulins. They were compared with an untreated control group. No significant differences were observed between the two groups.

Bacterial infections during the first few days of life remain an important cause of neonatal morbidity and mortality, especially in the premature newborn. ${ }^{1}$ It has been reported that incidence of neonatal sepsis and its mortality rate decrease by the intravenous administration of polyvalent human gammaglobulins with an intact crystallisable fragment. ${ }^{23}$ We report a randomised, controlled, blind study that was performed to determine whether intravenous immunoglobulins are able to prevent sepsis in premature newborn infants.

\section{Patients and methods}

From 1 May 1984 to 30 June 1986, 94 premature newborn infants with gestational age $\leqslant 34$ weeks (mean (SD) $31(2 \cdot 5)$, range 26-34) or birth weight $\leqslant 1500 \mathrm{~g}$ (mean (SD) 1340 (235), range 870-1790) or both, were randomly assigned to a group receiving immunoglobulin treatment or to a control group (no immunoglobulin treatment). Conditions at birth that precluded enrolment of babies into the study included multiple life threatening congenital anomalies, maternal infection, and cardiopulmonary arrest. With parents' permission 46 unselected infants were given $0.5 \mathrm{~g} / \mathrm{kg}$ intravenous immunoglobulin on the 1st, 2nd, 3rd, 7th, 14th, 21st, and 28th day of life. The product we used, Venogamma Polivalente (Ismunit, Pomezia, Italy), consists of human immunoglobulins obtained from the second fraction of Cohn-Oncley and treated with polyethyleneglycol (PEG 4000). It contains about $50 \mathrm{~g} / 1$ IgG, less than $0.3 \% \mathrm{IgA}$, and less than $10 \mathrm{IU} / \mathrm{ml}$ IgE. The IgG subclasses are distributed as in normal serum. Besides numerous antiviral antibodies this immunoglobulin preparation contains a large range of antibacterial antibodies (for example, those to $E$ Coli, Klebsiella, Pseudomonas, Streptococcus).
Serum IgG and IgM concentrations were determined before and 24 hours after every infusion of immunoglobulin by a nephelometric method. IgE was measured by radioimmunoassay. On the first day of life the following laboratory examinations were performed: culture of blood, stool, and gastric aspirate; white blood cell count (normal range $\left.5-30 \times 10^{9} / 1\right)$, band/total neutrophils ratio (normal value $<0 \cdot 2$ ); platelet count (normal value $>100 \times 10^{9} / 1$ ); serum concentration of IgM (normal value $<0.30 \mathrm{~g} / \mathrm{l}$ ); semiquantitative latex assay of C-reactive protein (normal value $<0.008 \mathrm{~g} / \mathrm{l}$ ) serum fibrinogen concentration (normal range $2-2.50 \mathrm{~g} / \mathrm{l}$ ); haptoglobin (normal value $<0.40 \mathrm{~g} / \mathrm{l}$ ), and serum concentration of $\alpha$-1-acid glycoprotein (normal value $<0.25 \mathrm{~g} / \mathrm{l})$.

These examinations were repeated when sepsis was suspected. The diagnosis of 'proven' sepsis was made when blood culture or cerebrospinal fluid culture, or both, were positive for a pathogen and were associated with clinical signs of neonatal systemic infection. The incidence of 'proven' and 'very probable' sepsis (clinical signs and changes in laboratory measurements that suggested general infection but without a positive blood culture) in the group of infants treated with immunoglobulin was compared with that of 48 newborn infants (control group) with the same gestational age, birth weight, combined antibiotic treatment (where used) and perinatal risk factors of infection. ${ }^{1}$

We excluded six treated infants: three underwent an exchange transfusion, two died of severe respiratory distress syndrome on the 2 nd and 3rd day of life respectively after a single dose of immunoglobulin, and one had suspected prenatal infection. Eight control babies were also excluded: two had an exchange transfusion, three died of severe respiratory distress syndrome on the 3rd day of life, one died of respiratory distress syndrome and intracranial haemorrhage on the 10th day, and two had suspected prenatal infection. Sepsis was not the reason for the exchange transfusion or the cause of the death in any infant. The Student's $t$ test and $\chi^{2}$ analysis were used for statistical evaluation.

\section{Results}

There were no significant differences between the 
Table 1 Clinical features of infants with 'proven' and 'very probable' sepsis

\begin{tabular}{|c|c|c|c|c|}
\hline $\begin{array}{l}\text { Case } \\
\text { No }\end{array}$ & Sex & $\begin{array}{l}\text { Birth } \\
\text { weight } \\
\text { (g) }\end{array}$ & $\begin{array}{l}\text { Age at } \\
\text { onset } \\
\text { (days) }\end{array}$ & $\begin{array}{l}\text { Clinical } \\
\text { signs }\end{array}$ \\
\hline
\end{tabular}

\begin{tabular}{|c|c|c|c|c|}
\hline 1 & $\mathbf{M}$ & 950 & 11 & Convulsions, cyanosis, vomiting, apnoea \\
\hline 2 & $\mathbf{M}$ & 1000 & 4 & Lethargy, cyanosis, hypotonia \\
\hline 3 & $\mathbf{F}$ & 870 & 4 & Cyanosis, hypotonia, \\
\hline 4 & $\mathbf{M}$ & 1700 & 16 & Apnoea, bradycardia, hypertonia \\
\hline 5 & $\mathbf{F}$ & 1140 & 5 & Convulsions, lethargy, sclerema \\
\hline 7 & $\mathbf{M}$ & 1440 & 7 & $\begin{array}{l}\text { Prolonged rupture of membranes, hypotonia, } \\
\text { convulsions, lethargy }\end{array}$ \\
\hline 8 & $\mathbf{M}$ & 1200 & 2 & Convulsions, sclerema, hypotonia \\
\hline 9 & $\mathbf{F}$ & 1000 & 4 & Cyanosis, lethargy, vomiting, apnoea \\
\hline 11 & $\mathbf{M}$ & 1100 & 25 & Convulsions, hypotonia, cyanosis, bradycardia \\
\hline 12 & $\mathbf{M}$ & 1500 & 3 & Convulsions, sclerema, hypotonia, fever \\
\hline 13 & $\mathbf{M}$ & 1090 & 2 & Convulsions, sclerema, hypotonia, bradycardia \\
\hline 14 & $\mathbf{F}$ & 1030 & 2 & Lethargy, cyanosis \\
\hline
\end{tabular}

mean (SD) baseline IgG concentrations in the treated $(5 \cdot 12(2 \cdot 31) \mathrm{g} / \mathrm{l})$ and the untreated infants $(5.99(2.42) \mathrm{g} / \mathrm{l})$. Although serum IgG concentrations were subject to important individual variations infusions of $0.5 \mathrm{~g} / \mathrm{kg}$ intravenous immunoglobulin were sufficient to obtain serum IgG concentrations that were constantly higher than $8.00 \mathrm{~g} / \mathrm{l}$.

Table 1 summarises the main features observed in patients with sepsis. The incidence rates of proven or very probable sepsis, mortality for sepsis, and total mortality during the first $\mathbf{4 0}$ days of life in the infants receiving intravenous immunoglobulin were not significantly different $(p>0 \cdot 1)$ when compared with those in the control infants (table 2).

The incidence rates of minor infections (mucocutaneous candidiasis, lower urinary tract infections,

Table 2 Incidence rates of sepsis and mortality in premature infants treated with intravenous immunoglobulin

\begin{tabular}{llll}
\hline & $\begin{array}{l}\text { No (\%) } \\
\text { treated infants } \\
(n=40)\end{array}$ & $\begin{array}{l}\text { No (\%) } \\
\text { control infants } \\
(n=40)\end{array}$ & $p$ Value \\
\hline 'Proven' sepsis & $5(12.5)$ & $3(7.5)$ & $>0 \cdot 1$ \\
'Very probable' sepsis & $2(5)$ & $4(10)$ & $>0 \cdot 1$ \\
Mortality for sepsis & $5(12.5)$ & $3(7.5)$ & $>0 \cdot 1$ \\
Total mortality & $7(17.5)$ & $7(17 \cdot 5)$ & \\
\hline
\end{tabular}

subcutaneous abscess, conjunctivitis, gastroenteritis, and omphalitis) were $35 \%$ in treated and $40 \%$ in untreated newborn infants $\left(\chi^{2}=0.053, p>0 \cdot 05\right)$. In both groups the incidences of respiratory distress syndrome (diagnosed by clinical and radiological features), hyperbilirubinaemia (plasma bilirubin concentrations $>120 \mu \mathrm{mol} / \mathrm{l}$ ), hypoglycaemia (blood glucose concentration $<1.7 \mathrm{mmol} / \mathrm{l})$, and intracranial haemorrhage (diagnosed clinically and by ultrasound) were not significantly different except for hypocalcaemia (plasma calcium concentration $<2$ $\mathrm{mmol} / 1 ; 35 \%$ in treated infants $v 7.5 \%$ in controls, $\mathrm{p}<0.001)$.

Tolerance of the product was excellent: no newborn infant showed any local or general reaction either during or after infusions. Three infants showed a temporary increase in IgE from 10-18 to 28-38 IU/ml without concurrent side effects.

\section{Discussion}

Many premature infants have a deficiency of IgG, as the transplacental transfer of IgG from the mother increases appreciably after 32-33 weeks' gestation and the synthesis rates of immunoglobulins are very low in newborn infants. Moreover, the transplacentally acquired IgG does not protect the babies against all neonatal pathogens, and the primary 


\begin{tabular}{|c|c|c|c|}
\hline $\begin{array}{l}\text { Factors indicating } \\
\text { sepsis }\end{array}$ & $\begin{array}{l}\text { Site of positive } \\
\text { culture }\end{array}$ & $\begin{array}{l}\text { Causative } \\
\text { organism }\end{array}$ & Outcome \\
\hline \multicolumn{4}{|l|}{ Treated } \\
\hline \multirow[t]{2}{*}{$\begin{array}{l}\text { Leukopenia, } \alpha \text {-acid glycoprotein and } \operatorname{IgM} \\
\text { positive, thrombocytopenia }\end{array}$} & Blood, cerebrospinal fluid & $S$ epidermidis & Died \\
\hline & Blood, cerebrospinal fluid & $S$ aureus & Died \\
\hline $\begin{array}{l}\text { C-reactive protein positive, thrombocytopenia, } \\
\text { hyperfibrinogenaemia }\end{array}$ & Cerebrospinal fluid & $S$ epidermidis & Died \\
\hline $\begin{array}{l}\text { C-reactive protein, haptoglobin and } \\
\alpha \text {-acid glycoprotein positive, thrombocytopenia }\end{array}$ & Blood & Kl pneumonia & Survived \\
\hline $\begin{array}{l}\text { Leukopenia, C-reactive protein positive, } \\
\text { hyperfibrinogenaemia }\end{array}$ & Blood, cerebrospinal fluid & $S$ marcescens & Died \\
\hline \multirow{2}{*}{$\begin{array}{l}\text { C-reactive protein and } \alpha \text {-acid glycoprotein } \\
\text { positive, hyperfibrinogenaemia }\end{array}$} & & & Died \\
\hline & & & Survived \\
\hline \multicolumn{4}{|l|}{ Controls } \\
\hline Leukocytosis & Blood, cerebrospinal fluid & $L$ monocytogenes & Survived \\
\hline $\begin{array}{l}\text { Leukopenia, haptoglobin, } \alpha \text {-acid glycoprotein } \\
\text { and IgM positive }\end{array}$ & Blood & $P$ aeruginosa & Died \\
\hline \multirow[t]{2}{*}{$\begin{array}{l}\text { Leukocytosis, C-reactive protein positive, } \\
\text { thrombocytopenia }\end{array}$} & Blood & $S$ marcescens & Survived \\
\hline & & & Survived \\
\hline Leukopenia, thrombocytopenia & & & Died \\
\hline Leukocytosis, C-reactive protein positive & & & Died \\
\hline Leukopenia, thrombocytopenia & & & Survived \\
\hline
\end{tabular}

antibody response to certain antigens is sluggish in neonates. In addition, the transient opsonic defect is more pronounced in premature infants. ${ }^{4}$

For these reasons some workers have conducted controlled studies in premature infants to determine whether infections could be decreased by giving intramuscular human immune serum globulin. ${ }^{5}$ These studies, however, do not provide a definite answer. The availability of intravenous immunoglobulin allowed us to carry out a study giving large doses to premature infants aimed at the prevention of infections in the first month of life. The schedule we used was necessary for the achievement and maintenance of serum IgG concentrations similar to those normally observed in full term infants. Nevertheless, our data show that the administration of intravenous immunoglobulin did not reduce the incidence of sepsis and mortality due to sepsis in the neonatal period. On the contrary, a recent study suggests that intravenous immunoglobulin is useful for prevention of sepsis in premature neonates, who are appreciably hypogammaglobulinaemic, in developing countries. ${ }^{2}$ Our results are understandable in the light of the complex immunologic deficit of the newborn infant-chiefly the preterm infantaffecting all specific and non-specific defence mechanisms. The immunoglobulin infusion really corrects this deficit only in part.
No adverse effects were noted after immunoglobulin transfusions in our subjects. The higher incidence of hypocalcaemia in the treated group cannot be clearly explained, but if this is confirmed it makes the routine use of intravenous immunoglobulin even more questionable.

The authors thank Miss Leonie Gane for her secretarial help.

\section{References}

1 Eriksson M. Neonatal septicemia. Acta Paediatr Scand 1983;72: 1-8.

${ }^{2}$ Haque KN, Zaidi MH, Haque SH, Bahakim H, El-Hazmi M, El-Swailam M. Intravenous immunoglobulin for prevention of sepsis in preterm and low birth weight infants. Pediatr Infect Dis 1986;5:622-5.

${ }^{3}$ Sidiropoulos D, Bohme U, von Muralt G, Morell A, Barandun S. Immunoglobulin-substitution bei der behandlung der neonatalen sepsis. Schweiz Med Wochenschr 1981;44:1649-55.

4 Yoder MC, Polin RA. Immunotherapy of neonatal septicemia. Pediatr Clin North Am 1986;33:481-501.

5 Amer J, Ott E, Ibbott FA, O'Brien D, Kempe CH. The effect of monthly gammaglobulin administration on morbidity and mortality from infection in premature infants during the first year of life. Pediatrics 1963;32:4-9.

6 Steen JA. Gamma globulin in preventing infections in premature infants. Archives of Pediatrics 1960;77:291-4.

Correspondence and requests for reprints to Professor A Stabile, via Cortina d'Ampezzo, 60-00135 Roma, Italy.

Accepted 14 October 1987 